\title{
Contextualizing an EFL teacher's beliefs about grammar teaching
}

\author{
Gloria Gil \\ Universidade Federal de Santa Catarina \\ Marcia Regina Pawlas Carazzai \\ Universidade Estadual do Centro-Oeste
}

\begin{abstract}
This article reports on a qualitative study that focused on an EFL teacher's beliefs and her practices concerning grammar teaching. The study aimed at investigating how the teacher's beliefs could be contextualized with classroom data. In the first stage of data collection and analysis, an open questionnaire was given to the teacher. Then, as a means of contextualizing the beliefs found in the analysis of the questionnaire data, the second stage of data collection and analysis focused on episodes from the teacher's classes. The analysis of the data shows that, according to this teacher, grammar teaching should be used as a facilitative device in order to help students in their learning process. The results of this study also indicate that the teacher's beliefs are influenced by three interactive sources: cognitive, contextual and experiential.
\end{abstract}

KEY-WORDS: beliefs, grammar teaching, English language

RESUMO: Este artigo reporta um estudo qualitativo que enfocou as crenças e práticas de uma professora de inglês-LE relacionadas ao ensino da gramática. O estudo objetivou investigar como as crenças da professora poderiam ser contextualizadas com dados da sala de aula. No primeiro estágio de análise e coleta de dados, um questionário foi aplicado à professora. Posteriormente, para contextualizar as crenças encontradas na análise do questionário, o segundo estágio de análise e coleta de dados enfocou episódios das aulas da professora. A análise dos dados mostrou que, de acordo com essa professora, o ensino da gramática deveria ser usado como um recurso facilitador para ajudar os alunos em seus processos de aprendizagem. Os resultados também indicaram que as crenças da professora são influenciadas por três fatores interativos: cognitivo, contextual e experiencial.

PALAVRAS-CHAVE: crenças, ensino da gramática, língua inglesa

\section{Introduction}

Qualitative research approaches the classroom in a descriptive and interpretative way, aiming at understanding teachers' and students' 
behaviors, intentions and perspectives. Recently, within this type of research, scholars have also started to investigate teachers' cognitions, ${ }^{1}$ on the premise that teachers' practice can be better understood by accessing the beliefs underlying such practice (FREEMAN; RICHARDS, 1996).

Despite the growing number of studies focusing on foreign language teachers' beliefs that have been undertaken (JOHNSON, 1992; GIMENEZ, 1994; FELIX, 1999; BARCELOS, 2000, for example), only a few studies have addressed language teachers' beliefs about grammar teaching (BORG, 1998, 1999, 2001, for example).

This paper tries to fill this gap, by reporting on a qualitative study of an English as a Foreign language (EFL) teacher's beliefs and behaviors related to grammar teaching. The objective of the study was to contextualize the teacher's beliefs with her practice in classroom, that is, to verify how the teacher's beliefs were expressed in terms of teaching practice.

This article is divided in 6 sections. Sections 2 and 3 present the review of the literature, which includes studies on beliefs, and studies on teachers' beliefs about grammar teaching, respectively. Section 4 describes the methodology used to collect and analyze data and the context of research. In section 5, the results and the discussion are presented. Lastly, in section 6 , the final remarks of the paper are presented.

\section{Beliefs: a contextual approach}

According to Pajares (1992), in studies on beliefs, different terms, such as beliefs, conceptions and knowledge are used to refer to the same thing, making the definition of the term confusing.

To fit the purpose of the present study, the term 'belief' is defined according to Pajares (1992, p. 316): "an individual's judgment of the truth or falsity of a proposition". ${ }^{2}$ This definition was chosen because, for Pajares, beliefs can be inferred both from what people say and from what people do, and thus, such definition allows us to contextualize an EFL teacher's beliefs about grammar teaching with her practice, that is, to have a contextual approach to the study of beliefs (BARCELOS, 2001).

\footnotetext{
${ }^{1}$ In this paper "cognitions" is used as an umbrella term that includes: beliefs, opinions, perceptions, etc.

${ }^{2}$ Even though we recognize the social origin of beliefs, we have chosen this as the operational definition in our paper.
} 
The contextual approach to investigate beliefs was discussed by Barcelos (2001). In her paper, Barcelos categorizes the studies about beliefs in three approaches: the normative approach, the metacognitive approach, and the contextual approach. According to the author, in the normative approach, beliefs are seen as explanation for students' behaviors, in a causeeffect relationship, and such beliefs are inferred from a pre-established set of sentences with which students should agree or disagree (likert-scale). In the metacognitive approach, beliefs are seen as metacognitive knowledge ("theories in action") and are verified by means of interviews and students' reports. In the contextual approach, beliefs are seen as embedded in students' context, and the studies that follow this approach use ethnography, narratives and metaphors to investigate beliefs.

Although Barcelos' (2001) categorization refers more specifically to studies about students' beliefs, it would be possible to establish a parallel and suggest that teachers' beliefs can also be studied from these three approaches proposed by her. Barcelos herself, while commenting about teachers' beliefs states that "[t]he studies (...) have indicated the need to investigate language teachers' beliefs in context, that is, in the classroom" (BARCELOS, 2000, p. 69).

\section{Beliefs about grammar teaching: Borg's studies}

Borg's $(1998,1999,2001)$ papers are examples of studies with a contextual approach to the investigation of teachers' beliefs about grammar teaching. His articles are mainly based on the results of qualitative research carried out with five in-service EFL teachers, in two EFL schools in Malta.

For his study, the author had a preobservation interview with the teachers, observed the teachers for 15 hours taking field notes and writing an analytic memo, and had a postobservation interview with the teachers. Borg's aim was to provide an emic perspective on the manner in which these teachers' practice was influenced by their cognitions, thus he described classroom practice related to grammar teaching and interpreted such data based on the interviews.

Borg's papers provide a better understanding of teachers' practices and cognitions about grammar teaching, by describing teachers' cognitions, their sources and the way such sources influence teachers' practices. More specifically, the author argues that such beliefs can be influenced by three interactive sources which shape teachers' decisions in relation to grammar 
teaching: contextual sources, cognitive sources, and experiential sources. The contextual sources can be seen as the aspects which involve the educational context itself, such as the classroom; the cognitive factors are related to the conceptions teachers hold about the knowledge of a L2, ${ }^{3}$ language teaching and learning, which were generated by their own experiences; and the experiential sources refer to the teachers' educational and professional experiences.

The study reported here draws mainly on Borg's papers mentioned above, as it tries to understand the types of beliefs which an in-service EFL teacher holds about grammar and the teaching of grammar, the sources which influence these beliefs, and the way such beliefs are expressed in her teaching practice.

\section{Methodology}

Data discussed in this paper are part of a larger qualitative study (CARAZZAI, 2002) with nine in-service EFL teachers who worked at an extra curricular language course at Universidade Federal de Santa Catarina (UFSC). This article focuses on one participant of the study, here named Terri.

When data were collected, Terri had been teaching EFL for ten years mainly at language institutes. She also taught at primary and secondary levels in private schools, and private classes at home as well. She preferred to teach small groups of adult learners. She took an undergraduate course in Letras and was enrolled in an MA course in Applied Linguistics at UFSC during data collection. Terri was very open to participate in the study, probably because her research interest was also related to grammar teaching, although her study was focused on the interactions which happen between students and teachers when they talk about grammar.

Data collection was carried out in two stages. In the first stage, an open questionnaire (APPENDIX A) with 15 questions was given to the nine teachers, in order to discover their beliefs about grammar teaching. The questions varied from teachers' professional and educational background

\footnotetext{
${ }^{3}$ In Borg's (1999) study, the cognitive sources of influence refer to the types of conceptions teachers have about L2 teaching and learning. In the present study, the concept was expanded to adapt to the data, and also includes the evaluation the teacher made about her knowledge of the English language grammar and the teacher's perceptions of her knowledge about grammar (KAG) (BORG, 2001).
} 
to definitions of grammar and role of grammar in the foreign language classroom. The questionnaire was written in Portuguese in order to facilitate the teachers' comprehension and answering, and it was applied in the second semester of 2001. Here in this paper, only the questionnaire responded by Terri is analysed.

As a means of contextualizing the beliefs found in the analysis of the questionnaire data, the second stage of data collection focused on Terri's classes. More specifically, ten classes (1h30min each) were observed in the first semester of 2002. In the group that Terri was teaching, there were 20 adult students ( 12 female and 8 male). The group was in the fourth semester of the ECLC program. The course was English IVA, which corresponds to a pre-intermediate level. The material adopted by the Extracurricular course is the New Interchange series, by Richards (1990). The classes were fully transcribed using transcription conventions adapted from Hatch (1992). Due to space constraints, however, only the episodes ${ }^{4}$ were used in this paper.

The model of data analysis adopted in the study followed Spradley's $(1979,1980)$ model of analysis. More specifically, this analysis consisted of discovering in the data phrases, sentences or episodes that revealed the beliefs and practices related to grammar teaching. This analysis was carried out in three stages: (a) from the reading of the data, (b) common themes emerge and (c) such themes are, then, categorized.

In the next section, the teacher's beliefs and behaviors related to grammar teaching are presented; they are illustrated with answers given by Terri to the questionnaire and episodes from her classes.

\section{Results and discussion}

The first apparent feature in relation to Terri's beliefs about grammar is the importance she seemed to give to it. This could be verified both because grammar teaching was very recurrent in the classes observed, and also because of Terri's belief that grammar teaching (or formal instruction, according to Ellis, 1994) should play a central role in the teaching of a foreign language, as shown in the excerpt below:

\footnotetext{
${ }^{4}$ According to Wells (1993, p. 5), an episode can be a segment of an educational activity, such as a class, in which actions are goal-directed and have a hierarchical organization.
} 
Q: What is your opinion about grammar teaching in the EFL classroom? Is it important and/or necessary or not?

A: Once I mentioned that grammar is the structure of a language, it could be said that it is fundamental in the teaching of a foreign language. What can be differentiated in this case is if grammar is taught implicitly or explicitly. Both forms can be used while teaching a language, based on students' needs and the complexity of content, and also based on the emphasis the teacher wants to give. (Q02)

The fact that grammar teaching was very recurrent in Terri's classes could also be explained by her belief that her knowledge about English language grammar is above average, as can be seen in the excerpt below:

I believe I master grammar well, although I still have a lot to learn and some things to repair consciously. (Q15)

According to Borg (2001), teachers' perceptions of their knowledge about grammar (KAG) may be one factor influencing their instructional decisions in teaching grammar. As the author remarks, teachers who are more confident of their KAG are more prone to "conduct regular, impromptu grammar work" (BORG, 2001, p. 24). Such perceptions are interpreted in this study as cognitive sources of influence, even though Borg (2001) did not classify KAG as a cognitive source of influence.

From the data analyzed, it was possible to see that Terri had three different types of recurrent behaviors in relation to grammar teaching that reflected the beliefs expressed in the questionnaire: the use of terminology as a device to communicate with students while teaching grammar, the attempt to engage her students in the classroom while explaining or revising grammar, and the drawing of students' attention by means of formulation of rules of thumb or by providing corrective feedback.

In the following subsections, these three types of behavior are explained, and they are illustrated with one example from a classroom episode along with a commentary, as well as an excerpt from Terri's answers to the questionnaire that in some way is related to her behavior.

\footnotetext{
${ }^{5}$ References to the data in this paper follow these conventions: "Q" refers to questionnaire question; "A" refers to the answers given by the teacher; "Q02" refers to question 02 . The translated versions of the answers to the questionnaire were also done by ourselves. "T" is the teacher. S1, S2, SS, etc. refer to individual or groups of students.
} 


\section{Using terminology}

Terri made use of terminology mainly as a communicative device, i.e., she used terminology in order to communicate with her students more easily while explaining or revising a grammar structure.

In the following example, Terri is revising the use of the simple past tense. She engages students in this revision by means of dialogue. During the review, it can be seen that terminology allows students to label concepts Terri seems to believe they already know how to apply (lines 253-6). Terri exposes her students to terminology, but she does not make demands on the students to study and reproduce it:

251. T: ok + do you have any questions about this grammar focus? ++ is it clear for you? ++ really? + very clear? ++ so here we have (xxxxx) + so in this first one + they are talking about past + the second about past + and the third one about future + ok? so in the past + how can you use the verb in the past? +++ to talk about past + about events in the past + about time in the past? +++

252. S: were + were

253. T: was/were + if it the verb + is the verb to be + right?

254. S: right

255. S: ed?

256. T: ed? or you put ed + with what kind of verb?

257. S: regular

258. T: REGULAR verbs + very good + + and irregular verbs? what about irregular verbs?

259. S: you use the form

260. T: you use the form ++ what is the form in: + in the column + what + what is the column? ++ the first + the second or the third?

261. S: $(\mathrm{xxxxx})$

262. T: ah?

263. S1: present past

264. S2: past participle ((having difficulty to pronounce 'participle'))

265. T: past participle + do you + remember that list of irregular verbs?

266. S: (xxxxx) 
267. T: ah?

268. S: $(\operatorname{xxxxx})$

269. T: I think + everybody has studied that list + yes?

270. S: yes

271. T: [or DID that list + yes did + ok + so the first column + remember + I think you have it here in your book + I'm not sure + yes?

272. S: yes

273. T: remember? which page? ((browsing the book)) oh yes ++++++ ((browsing the book)) oh yes + let's see + thank you Jul ++ so here + do you remember + here you have irregular verbs + ok? In book one + you have too + in the end of the book you have + I think that you have $\mathrm{a}+\mathrm{a}$ longer list + there in book + in book one + ok? and + so + remember the irregular verbs + ok? + you have in the first column the present + in the second the past + SIMPLE past + and in the third the participle + past participle + ok? so here + we are using the + simple past + the + second column + right? + ok + or + either you use simple past + or ++ or what + to talk about past + events in the past?

274. S1: past perfect?

275. S2: used to

276. T: used to + ok + ok + ok + not past perfect

277. S1: no?

278. T: no + + forget about names + right

279. S1: right

280. T: not here ++ ok + eh: so here you have + two different ways to talk about the past + right? or you use + only the verb in the past + or you use used to + ok + remember that + well $((\ldots))$

In the same example it is also possible to observe that Terri prefers to talk about the $1^{\text {st }}, 2^{\text {nd }}$, and $3^{\text {rd }}$ columns instead of the infinitive, past simple and past perfect, respectively. Terri also used the word 'form', in a reproduction of the term offered by a student (lines 258-60). These practices show that Terri opted for less technical words when they were available. Therefore, it could be argued that Terri used terminology as a facilitator in the teaching/ learning process, but it was not the focus of her discourse. This idea was 
also validated by Terri in one of her answers to the questionnaire. When asked if she used terminology in order to teach grammar, Terri answered affirmatively, but she mentioned that terminology is not her point of departure:

Q: When you teach grammar, do you use terminology to teach it? (e.g. 'subject', 'verb', 'present continuous')? Why?

A: $\quad$ Sometimes I do it, mainly while explaining more complex grammar structures, for example the present perfect. Generally, I mention terminology after the explanation, I do not use it as a point of departure. (Q05)

\section{Engaging students}

A common behavior in Terri's classes was to engage students in explaining or revising a certain grammar structure. In the example below a student raises a doubt about the difference between direct and indirect questions. The student herself/himself does not seem to see the difference (line 631):

630. T: no + no + what is direct and indirect questions?

631. Aud: (xxx) no + é (xxx) não tem + eu não consigo + visualizar a diferença + a não ser quando é + quando tem que colocar o verbo + antes

632. T: ok + you don't know the difference between direct and indirect + yes?

633. Aud: yes

634. T: ok + what's the difference?

635. Ss: $(\mathrm{xxx})$

636. S: esse é indirect

637. Ss: (xxx)

638. T: what's the difference between them? ++ do you know? + uh? + for example + eh: if I ask you + where is the bank?

((T writes on the board)

639. T: ++ is this direct or indirect?

640. Ss: direct

641. T: how can I put this into indirect question?

642. S: do you know where ( $\mathrm{xxx})$

643. S: where the bank is? 


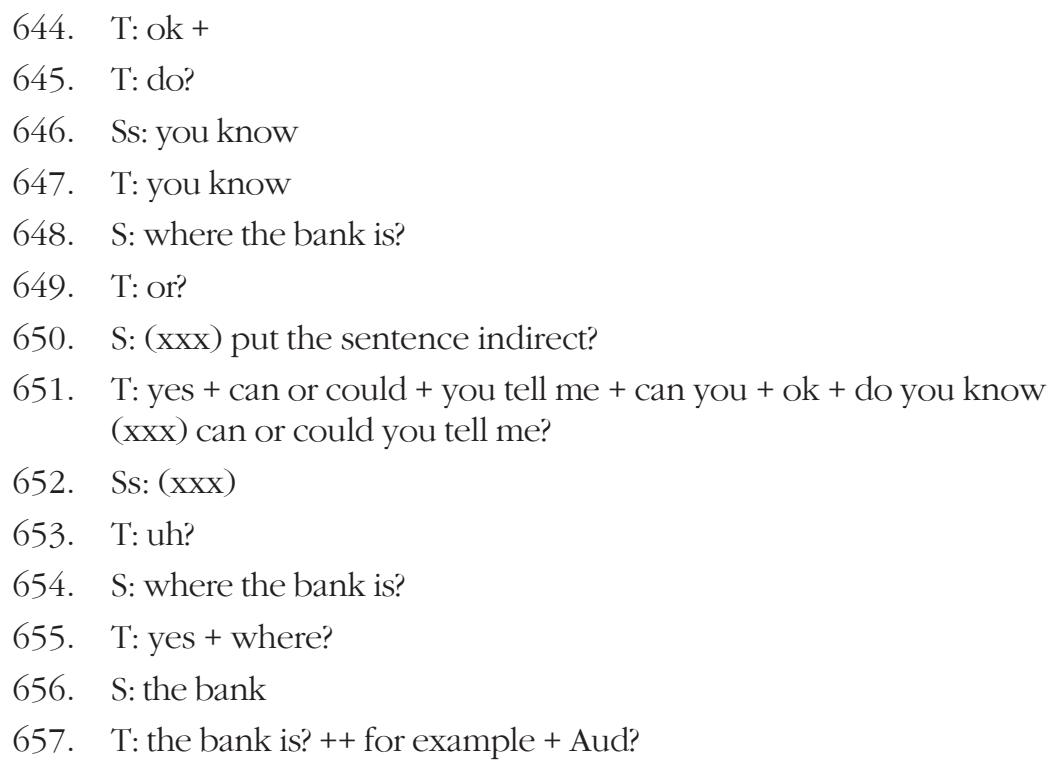

Terri sees the student's difficulty, and tries to engage the whole group in solving the doubt (lines 632-8), and, thus, she gives students the authority and control of the activity. When Terri realizes students still have difficulty in identifying the difference, she gives them a simple example (lines 6389) and continues gradually until the students can construct both direct and indirect questions. Terri herself does not provide the answers, she only helps the students to construct the direct and indirect questions by themselves, probably because she expects students either to know the answers, or to try to learn in that manner. In this way, Terri creates a challenging, but supportive environment for learning.

By engaging students in the classroom, Terri puts them in the center of the learning process. This classroom practice demonstrates Terri's concern with her students and was corroborated by an answer she gave in the questionnaire. Terri makes it clear that her students, with their characteristics and objectives, are central in the teaching of grammar in her classes, and reveals that she was influenced by the contextual sources of influence proposed by Borg (1999). The excerpt below shows Terri's answer when questioned about her students and their characteristics:

Q: When you teach grammar, do you take into consideration your students' characteristics (their objectives, age and proficiency level)? In what way? 
A: Of course! All these characteristics, variables, together with the students' objectives are very relevant. Departing from this, I see how, what and why I am going (should) teach grammar, always respecting the learner's limitations. (Q08)

\section{Drawing students' attention}

In her classes, Terri frequently used grammar teaching in order to draw students' attention to certain aspects or structures of the target language. This could be observed mainly when Terri provided corrective feedback to her students and when she formulated rules of thumb. ${ }^{6}$

The example below shows a moment in which students were reading sentences they had done for homework. When a student makes a mistake, Terri not only explicitly corrects the student, but she also formulates a rule of thumb (line 132):

129. S: if I quit smoking + I might to breath better

130. T: ok + I might?

131. S: I might to breath better $+(\mathrm{xxx})$

132. T: ah + breath $(($ emphasizing pronunciation $))+$ I might BREATH + this is might + might + might breath + ok + after might people + you have to use the verb + without to + ok ++ might + ok ++ yes

133. Ss: $(\mathrm{xxx})$

134. T: no + after modal + after + can + could + might + may ++ you never use the verb with to + only after ought

135. S: ah

136. T: this is an exception + right + ought to + right + only this one + ok? + ok + Mat?

It could be said that Terri takes the opportunity to reinforce a rule which she considers basic, and, thus, she believes students have to know.

\footnotetext{
${ }^{6}$ According to the Longman dictionary of contemporary English (1987, p. 914) a rule of thumb is "a principle or method based on practical sense and experience rather than exact rules or calculation". Berman (1979) has defined a rule as "an explicit generalization in the form of a verbal formulation ... about some aspect or feature of the target language" (BERMAN, 1979, p. 279-80). Thus, a rule of thumb is here interpreted as an explicit generalization formulated by the teacher based on her practical sense and experience in order to provide students with helpful and appropriate principles about the target language.
} 
In this way, Terri draws the students' attention to the appropriate form and tries to emphasize the importance of the rule. Further in the same class, another student makes a similar mistake and Terri refers to the rule of thumb in order to help the student correct the mistake by herself/himself:?

195. S: if I don't get good grades in school + I might to study a lot

196. T: I might?

197. S: to study a lot

198. T: remember the explanation ((the teacher is referring to the previous explanation))

199. S: ok + I might study a lot

200. T: yes

It could be argued that Terri used corrective feedback and the formulation of rules of thumb as a means of focusing on form. As already mentioned, the teacher was enrolled in an MA during data collection, and thus, was familiar with the theories on which this study is based. Terri was especially interested in Long's (1997) $)^{8}$ focus on form theory, and used it as the foundation of the thesis she was writing. Thus, in the answer below it can be seen how Terri seems to appropriate the idea of focus on form and believe that this is an important practice for the learning of a foreign language:

Q: Do you teach grammar in your classes? Why?

A: Yes, because it is important. Without grammatical explanations, students feel lost, most of the times. At first, I try to teach grammar in an implicit way. When I see that the students have difficulty, I focus on form so that they consciously notice how the process of language construction works. (Q03)

\footnotetext{
${ }^{7}$ For more details on how Terri provided feedback to her students' mistakes, see Carazzai (2003), Carazzai and Bergsleithner (2004), and Rauber and Gil (2005).

${ }^{8}$ According to Long (1997), "[f]ocus on form refers only to those form-focused activities that arise during, and embedded in, meaning-based lessons; they are not scheduled in advance (...) but occur incidentally as a function of the interaction of learners with the subject matter or tasks that constitute the learners' and their teacher's predominant focus".
} 
Terri's behavior thus reflects her concern in teaching students in a way that their attention is "briefly shifted to linguistic code features, in context, when students experience problems as they work on communicative tasks", or what Long calls focus on form (1997). Terri's objective is not simply to teach discrete grammar points or isolated linguistic structures (focus on forms, according to Long, 1997). Such behavior could be interpreted as the result of an experiential source of influence, since Terri herself, as a student, realized how important it is for students to engage in communicative activities, rather than only in formal ones, as seen in the following excerpt:

Q: $\quad$ Comment on your education as a student. What kind of experiences did you go through? Was grammar taught, when you learned English?

A: It was structural, Chomskyan. Only at the end of the course, the didactics classes we started to talk about the communicative approach. However, such approach was focused on our teaching, not on our learning. (Q13)

\section{Final remarks}

This paper aimed at contextualizing an EFL teacher's beliefs about grammar teaching with her practice in a pre-intermediate level classroom.

The results show that in Terri's classes, grammar teaching was very frequent. Her most recurrent practices were drawing students' attention and engaging students in the activities she proposed.

This high frequency of grammar teaching in Terri's classes could be mainly explained by the fact that Terri seemed to believe that formal instruction is a fundamental part of the L2 learning process, that is, a cognitive source of influence. Moreover, it is possible to explain Terri's behavior by the high level of confidence that she had on her knowledge about the English language grammar, that is, another cognitive source of influence, and by experiences she has gone through as a student, that is, an experiential source of influence. It should also be remarked that, although grammar teaching seemed to be a central concern of Terri herself, she planned and taught her classes focusing on her students', their needs, their objectives, that is, a contextual source of influence. Thus, it could be said that Terri's beliefs were influenced by the three interactive sources proposed by Borg (1999): contextual, cognitive and experiential.

In general, all the episodes analyzed, as well as the answers Terri gave in the questionnaire, demonstrate that her main concern when teaching 
grammar was to try to engage her students in all the tasks and activities she proposed. She constructed her classes in collaboration and negotiation with her students, and, through dialogue, involved the learners in searching for solutions of the problems that arose in their own FL learning. This dialogic relationship is defined by Donato and Adair-Hauk (1992) as proleptic instruction, a kind of formal instruction in which "individuals are challenged to re-create each others' perspective on the topic and task at hand" (DONATO; ADAIR-HAUK, 1992, p. 83). Therefore, from the analysis of the data, it could be concluded that Terri's strongest belief about grammar teaching is reflected mainly on the way she engaged students in their learning process.

\section{Acknowledgements}

We would like to thank Terri for participating in this study. We would also like to thank three anonymous reviewers for their comments on an earlier draft of this paper.

\section{References}

BARCELOS, A. M. F. Metodologia de pesquisa das crenças sobre aprendizagem de línguas: estado-da-arte. Revista Brasileira de Lingüística Aplicada, Belo Horizonte, v.1, n.1, p. 71-92, 2001.

BARCELOS, A. M. F. Understanding teachers' and students' language learning beliefs in experience: A Deweyan Approach. 2000. 357f. Tese (Doutorado em Ensino de Inglês como Segunda Língua) - College of Education, The University of Alabama, Tuscaloosa, 2000.

BERMAN, R. A. Rule of grammar or rule of thumb? IRAL, XVII/4, p. 279-302, 1979.

BORG, $S$. Teachers' pedagogical systems and grammar teaching: a qualitative study. TESOL Quarterly, 32/1, p. 9-38, 1998.

BORG, S. The use of grammatical terminology in the second language classroom: a qualitative study of teachers' practices and cognitions. Applied Linguistics, 20/1, p. 95-126. Oxford University Press, 1999.

BORG, S. Self-perception and practice in teaching grammar. ELTJournal, 55/1, p. 21-29. Oxford University Press, 2001.

CARAZZAI, M. R. P. Correção de erros na sala de aula de inglês como língua estrangeira: Considerações preliminares de um estudo etnográfico. In: SOUZA et al. Universidade: ação e interação. Guarapuava: Editora da Unicentro, 2003. p. 212-217. (Coleção Seminário de Pesquisa da UNICENTRO) 
CARAZZAI, M. R. P. Grammar and grammar teaching: A qualitative study EFL teachers' beliefs and behaviors. 2002. 143f. Dissertação (Mestrado em Letras/Inglês e Literatura Correspondente) - Universidade Federal de Santa Catarina, Florianópolis, 2000.

CARAZZAI, M. R. P.; BERGSLEITHNER, J. M. Um estudo colaborativo da correção de erros na sala de aula de inglês como língua estrangeira. In: Anais do 6트contro do CELSUL, 2004. A publicar.

DONATO, R.; ADAIR-HAUCK, B. Discourse perspectives on formal instruction. Language Awareness, 1(2), p. 73-89, 1992.

ELLIS, R. The study of second language acquisition. Oxford: Oxford University Press, 1994.

FÉLIX, A. Crenças de duas professoras de uma escola pública sobre o processo de aprender língua estrangeira. In: ALMEIDA FILHO, J. C. P. (Org.). O professor de lingua estrangeira em formação. Campinas: Pontes, 1999. p. 93-110.

FREEMAN, D.; RICHARDS, J. (Ed.). Teacher learning in language teaching. Cambridge: Cambridge University Press, 1996.

HATCH, E. Discourse and language education. London: Cambridge University Press, 1992.

JOHNSON, K. E. The relationship between teachers' beliefs and practices during literacy instruction for non-native speakers of English. Journal of Reading Behavior, 24 (1), p. 83-108, 1992.

Longman dictionary of contemporary English. Second edition. Essex: Longman, 1987.

LONG, M. H. Focus on form in task-based language teaching. 1997. Disponível em: <http://www.mhhe.com/socscience/foreignlang/conf/option3.htm>. Acesso em: 9 out. 2005.

GIMENEZ, T. N. Learners becoming teachers: an exploratory study of beliefs held by prospective and practicing EFL teachers in Brazil. Unpublished Ph.D. dissertation. Lancaster: Lancaster University, 1994.

RAUBER, A. S.; GIL, G. Correção de erros gramaticais de inglês-LE em ambiente comunicativo. In: GIL, G.; RAUBER, A. S.; CARAZZAI, M. R. P.; BERGSLEITHNER, J. M. (Ed.). Pesquisas qualitativas no ensino $e$ aprendizagem de inglês: A sala de aula e o professor de LE. Florianopolis: Editora do Programa de Pos-Graduação em Letras/Inglês e Literatura Correspondente, 2005. p. 149-166. 
PAJARES, F. Teachers' beliefs and educational research: cleaning up a messy construct. Review of educational research, 62/3, p. 307-332, 1992.

RICHARDS, J. C. New Interchange: English for international communication. Cambridge: Cambridge University Press, 1990.

SPRADLEY, J. P. Participant observation. Orlando: Harcourt Brace Jovanovich College Publishers, 1980.

SPRADLEY, J. P. The ethnographic interview. Orlando: Harcourt Brace Jovanovich College Publishers, 1979.

WELLS, G. Discourse as tool for doing science. In: ALLEN, P. (Ed.). Inquiry in the learning and teaching of science, 1995.

WELLS, G. Re-evaluating the IRF sequence: a proposal for the articulation of theories of activity and discourse for the analysis of teaching and learning in classroom. Linguistics and education, 5, p. 1-37, 1993. 


\section{APPENDIX A}

\section{A Gramática e o ensino da gramática: um estudo qualitativo das crenças e práticas de professores de inglês como língua estrangeira}

\section{Questionário}

1. O que significa 'gramática' para você?

2. Qual sua opinião sobre o ensino da gramática na aula de inglês (LE)? Ë importante e/ou necessário ou não? Explique.

3. Você trabalha a gramática na sua aula de inglês? Por quê?

4. Que tipo de atividades você usa para trabalhar a gramática na aula de inglês? Dê exemplos.

5. Você usa a terminologia para ensinar a gramática (ex. 'sujeito', 'verbo', 'presente contínuo')? Por que o faz?

6. Quando você ensina a gramática, você ensina também o contexto e o sentido da estrutura gramatical? Explique.

7. Se você fosse ensinar o 'can', como você faria?

8. Quando você ensina a gramática você leva em consideração as características do aluno (os objetivos de seu aluno, sua faixa etária, seu nível de inglês)? De que maneira?

9. Sob o seu ponto de vista, você acha que trabalhar a gramática ajuda o aluno? De que formas?

10. Você ensina a gramática por ela mesma, ou relaciona com outras habilidades (speaking, listening, etc.)? Explique.

11. Em qual habilidade você acha que os alunos precisam da gramática? Explique.

12. Comente sobre sua experiência profissional e sua formação como professor(a)? Há quanto tempo você leciona inglês? Em que tipo de escola e para que tipo de alunos?

13. Comente sobre sua formação como aluno(a). Por que tipo de experiências você passou? Quando você aprendeu inglês, a gramática era ensinada?

14. O fato de você ensinar, ou não, a gramática vem de sua formação como aluno(a) e/ou professor(a)? Explique.

15. Como você avaliaria seu conhecimento da gramática do inglês? 